(C) О.С. Каніковський, І.В. Павлик, І.В. Олійник, О.Л. Маховський, 2018

УДК 616.37-002-036.12-06:616.37-006]-08-035-059

\title{
Алгоритм лікування псевдокіст підшлункової залози у хворих на хронічний панкреатит
}

\author{
О.Є. Каніковський, І.В. Павлик, І.В. Олійник, О.Л. Маховський \\ ipavlyk@gmail.com
}

Вінницький національний медичний університет імені М.І. Пирогова, кафедра хірургії медичного факультету №2, Вінниия

\section{Реферат}

Вступ. Кількість хворих із кістами підшлункової залози збільшується разом із зростанням числа гострого і хронічного панкреатиту. Більша їх кількість потребує хірургічного лікування в зв'язку з наявністю ускладнень: інфікування, кровотечі, спонтанного розриву.

Мета дослідження. Аналіз результатів лікування кіст підшлункової залози та розробка алгоритму їх лікування.

Матеріали та методи. Проаналізовано результати хірургічного лікування 125 хворих з псевдокістами підшлункової залози, які лікувалися в клініці протягом 2000-2018 років. Всім хворим виконувалася комп'ютерна томографія, визначався тиск всередині кісти, а також рівень больового синдрому. Всі хворі залежно від гіпертензії були поділені на три групи.

Результати досліджень та їх обговорення. У хворих на кісти підшлункової залози виконували внутрішню декомпресію (61), зовнішню декомпресію (29), внутрішньо-зовнішню декомпресію (18), резекційні методики (12), ендоскопічну цистогастростомію (5). При неускладнених кістах підшлункової залози у 58,1\% (73) були умови для застосування методик внутрішньої декомпресії та резекційних методик. Натомість у 47 хворих з ускладненими кістами були застосовані методики зовнішньої (29) або комбінованої декомпресії (18).

Висновки. У випадку наявності розширеної головної панкреатичної протоки та чіткого зв’язку з просвітом кісти таким хворим показані резекційні методи оперативного лікування. Зовнішня декомпресія при рівні гіпертензії 2-3 супроводжується у $34,4 \%$ формуванням зовнішньої панкреатичної нориці, яка у $13,8 \%$ не закривається самостійно. Внутрішня декомпресія не супроводжується збільшенням кількості післяопераційних ускладнень і летальності.

Ключові слова: хронічний панкреатит, кісти підшлункової залози

Algorithm of pancreatic cysts treatment in patients with chronic pancreatitis Kanikovskyi O.E., Pavlyk I.V., Oliinyk I.V., Mahovskyi O.L.

Vinnytsia National M.I. Pirogov Memorial Medical University, Department of Surgery of the Medical Faculty №2, Vinnytsia

\section{Abstract}

Introduction. The number of the patients with pancreatic cysts recently increases with count of cases of acute and chronic pancreatitis. Most of them needs surgical treatment because of its complications: infection, bleeding, rupture.

The aim of our investigation were to analyze the results of pancreatic cysts treatment and development of its treatment algorithm.

Material and methods. The results of surgical treatment of 125 patients with pancreatic pseudocysts were submitted that treated from 2000 till 2018 years. All patients before surgery procedure did CT, we check pressure inside the pancreatic cysts and rate the severity of pain.

Results: Patients with pancreatic cysts were operated: internal draining (61), external draining (29), external-internal draining (18), local resection of pancreas (12), endoscopic cystogastrostomy (5). When cysts were without complication in $58.1 \%(73)$ we did internal draining and resectional procedures. In 47 patients with complicated cysts we did external draining (29) or combined external-internal draining (18).

Conclusion: If increased main pancreatic duct diagnosed and there are connection of main pancreatic duct with a cyst lumen that is indication to resectional procedure - local pancreatic resection by Frey-Izbicki. If there are present pancreativ hypertension the external draining accompanied with pancreatic fistula formation in $34.4 \%$, than in $13.8 \%$ need surgical procedure. Internal draining are safe surgical procedure with low postoperative morbidity and mortality.

Key words: chronic pancreatitis, pancreatic cyst

Вступ. Псевдокіста підшлункової залози акумуляція рідини в підшлунковій залозі або оточуючій клітковині. Як правило, вона оточена сформованою сполучнотканинною капсулою і містить несолідний компонент. Досвід хірургічного лікування псевдокіст нараховую більше сторіччя. Ефективність ендоскопічного ліку- вання псевдокіст підшлункової залози коливаєтья від 60 до 90\%, тоді як хірургічного втручання від 94 до 99\%. Зовнішнє дренування кіст асоціюється 3 великим ризиком, близько 30\%, ускладнень, які потребують в подальшому хірургічного лікування в близько $38 \%$ Хірургічне лікування псевдокіст підшлункової залози на- 
раховує більше 50 років досвіду. Псевдокісти підшлункової залози є ускладненням деструктивного процесу, який проходить у підшлунковій залозі та оточуючих тканинах при гострому та хронічному панкреатиті (ХП). Останніми роками кількість хворих 3 кістами підшлункової залози (ПЗ) збільшується паралельно 3 зростанням числа гострого і хронічного панкреатиту, а при деструктивних його формах частота формування кіст досягає 49-53,2\% хворих. Гострий панкреатит ускладнюється утворенням кіст в 4-21,3\% випадків. Період дозрівання таких кіст складає близько 2 місяців і $33 \%$ їх спонтанно розсмоктується [1]. Однак більша їх кількість потребує хірургічного лікування через наявність ускладнень: інфікування, кровотечі, спонтанного розриву $[2,3]$.

Мета дослідження. Аналіз результатів лікування кіст підшлункової залози.

Матеріали та методи. В хірургічній клініці медичного факультету №2 Вінницького національного медичного університету ім. М.І.Пирогова протягом 2000-2018 рр. проведено хірургічне лікування 125 хворих на хронічний панкреатит, ускладнений псевдокістами підшлункової залози. Чоловіків - 95, жінок 30 , середній вік $46,0 \pm 13,7$ року. У віковому діапазоні 30 - 59 років було $73,4 \%$.

Відповідно до Nealon's класифікації кіст підшлункової залози: тип 3 (не розширена протока 3 стриктурою без сполучення 3 кістою) - 47; тип 4 (не розширена протока 3 стриктурою та сполученням 3 кістою) - 66; тип 7 (розширена протока 3 сполученням 3 кістою) - 12 пацієнтів [5].

Стан підшлункової залози оцінювали відповідно до Марсельсько-Римської класифікації хронічного панкреатиту (1989), у пацієнтів 3 кістами додатково виявляли калькульоз підшлункової залози у 5 хворих, обструкція головної панкреатичної протоки у 78, фіброз ПЗ у 41 . Супутні захворювання були діагностовано у $108(86,4 \%)$ хворих [6].

Для оцінки гіпертензії нами визначався тиск у кісті підшлункової залози (16) опрацьованим методом (рішення від 14.10.2010 № 340/3У/10 про встановлення дати подання заявки на патент України на корисну модель «Прилад для виміру тиску в порожнинних органах). За рівнем панкреатичної гіпертензії у хворих на кісти підшлункової залози ми умовно виділили три ступені. Обгрунтування поділу на ступені панкреатичної гіпертензії залежало від співвідношенням із нормальними показниками тиску у системі проток підшлункової залози і позапечінкових жовчних протоках, враховуючи суттєву анатомо-функціональну спільність цих систем. При першому ступені рівень тиску не перевищував нормальні показники у системі проток підшлункової залози $(<200$ мм $\mathrm{H} 2 \mathrm{O}$ $(<1,96$ кПа)). При другій ступені - не переви- щував тиск у системі жовчних проток (<400 мм Н2О (1,96-3,92 кПа)). При третьому - перевищував тиск у поза печінкових жовчних протоках $(>400$ мм $\mathrm{H} 2 \mathrm{O}(>3,92$ кПа)).

Для оцінки ефективності корекції больового синдрому використовували опитувальник SF-36 показник «інтенсивність болю» (Р) та візуально-аналогову шкалу (ВАШ) [2,3].

Результати досліджень та їх обговорення. Всім хворим у передопераційному періоді виконували комп'ютерну томографію. За їі даними визначалася величина кісти, зв'язок їі з головним панкреатичним протоком, зрілість сті-

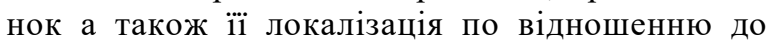
інших органів, особливо до дванадцятипалої кишки та задньої стінки шлунка.

Обсяг порожнини кісти визначали шляхом виміру в трьох проекціях по КТ, а також потім підтверджували інтраопераційно по об'єму евакуйованого вмісту. Ми умовно поділили кісти на «малі» (<100 мл) - 7 хворих; «середні» (1001000 мл) - 61 хворий; «великі» (>1000 мл)- 25 хворих. Нами визначена залежність внутрішньо порожнинного тиску від обсягу кісти. Так гіпертензія першого ступеня констатована у 75,0\% хворих на «малі» кісти, гіпертензія другої ступені - у 85,7\% хворих на «середні» кісти, гіпертензія третього ступеня - у 83,3\% хворих на «великі» кісти. Саме грунтуючись на цій залежності був проведений умовний поділ хворих на кісти.

Вміст кісти різнився за концентрацією ферментів. Рівнем амілази досліджували за Вольгемутом після інтраопераційної пункції кісти. Найбільша частка $(48,8 \%)$ хворих на кісти ПЗ була у діапазоні рівня амілази вмісту кісти 512-4096. Крім того, найбільші показники рівня амілази були констатовані при великих кістах. Таким чином, кісти середніх і великих розмірів із високими показниками рівня амілази вмісту (більше 512 од. за Вольгемутом) можуть оцінюватися як інтраопераційні ознаки панкреатичної гіпертензії.

Прослідковувалася пряма залежність інтенсивності больового синдрому від ступені панкреатичної гіпертензії. Серед хворих на кісти підшлункової залози при першому ступені підвищення тиску відповідно до опитувальника SF-36 показник «інтенсивність болю» (Р) склав $3,5 \pm 0,21$; відповідно візуально-аналогової шка-

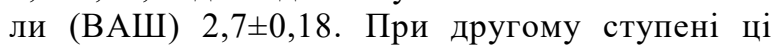
показники склали $\mathrm{P}=6,8 \pm 0,25 \quad(\mathrm{t}=10,0 ; \mathrm{n}=10$; $\mathrm{p}<0,01), \quad$ ВАШ $=5,5 \pm 0,32 \quad(\mathrm{t}=7,6 ; \mathrm{n}=10 ; \mathrm{p}<0,01)$. При третьому ступені $\mathrm{P}=10,7 \pm 0,52(\mathrm{t}=6,7 ; \mathrm{n}=11$; $\mathrm{p}<0,01)$, ВАШ $=8,2 \pm 0,44 \quad(\mathrm{t}=5,0 ; \mathrm{n}=11 ; \mathrm{p}<0,01)$. Коефіцієнт кореляції Фехнера (I) склав для першого ступеня 0,77 , для другої - 0,89, для третьої - 0,81 .

У хворих на кісти підшлункової залози виконували внутрішню декомпресію (61), зовнішню де- 
компресію (29), внутрішньо-зовнішню декомпресію (18), резекційні методики (12), ендоскопічну цистогастростомію (5). При неускладнених кістах підшлункової залози у 58,1\% (73) були умови для застосування методик внутрішньої декомпресії та резекційних методик. Натомість у 47 хворих з ускладненими кістами були застосовані методики зовнішньої (29) або комбінованої декомпресії (18).

Алгоритм вибору оперативного лікування зображений на рисунку 1. Принциповим питанням в лікуванні кіст підшлункової залози було наявність зв'язку порожнини 3 розширеною головною панкреатичною протокою підшлункової залози (Рис. 1). Якщо даний зв'язок підтверджувався інтраопераційно (Рис. 2) то в таких випадках всім хворим (12 хворих) виконувалася локальна резекція підшлункової залози в модифікації Фрея-Ізбіцкого (Патент України на винахід №103273 від 25.09.2013) 3 транспанкреатичною папілосфінктеротомією (Патент України на винахід №115291 від 10.10.2017 р.) (Рис. 2) [4].

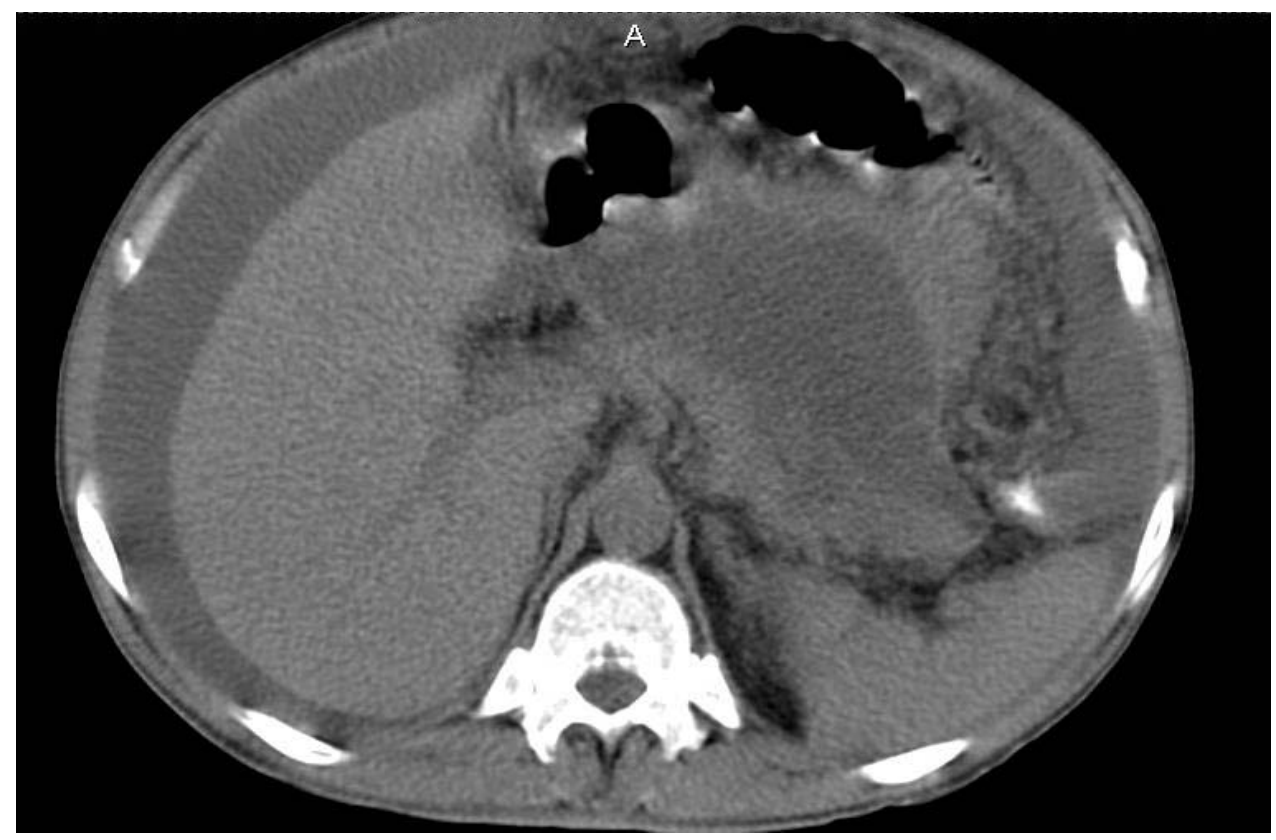

Рис. 1. Хворий Р., 43 роки. Д-з: Хронічний панкреатит, обструктивна форма 3 декомпресією головної панкреатичної протоки в просвіт кісти підшлункової залози.

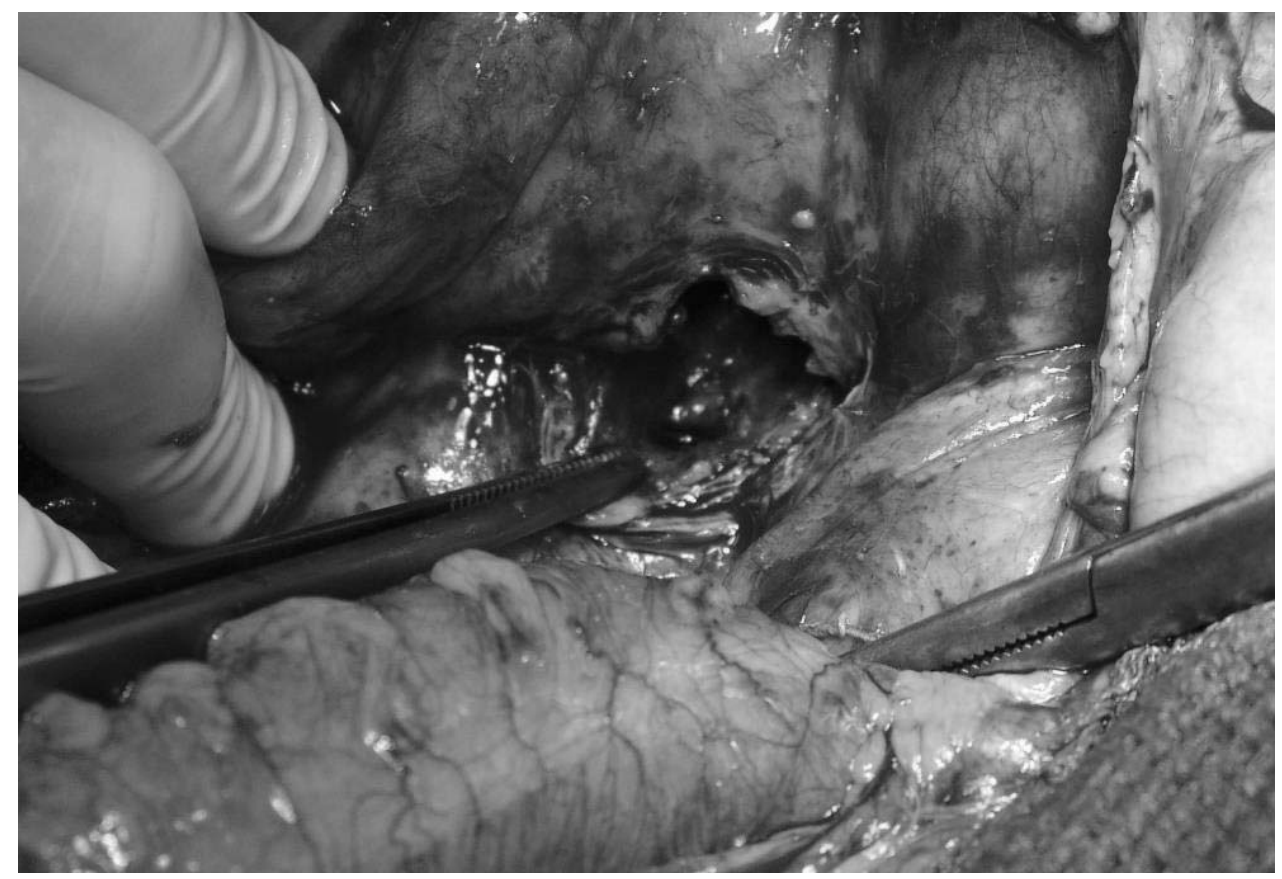

Рис. 2. Хворий В., 65 років. Д-з: Хронічний панкреатит, обструктивна форма 3 декомпресією головної панкреатичної протоки в просвіт кісти підшлункової залози. 


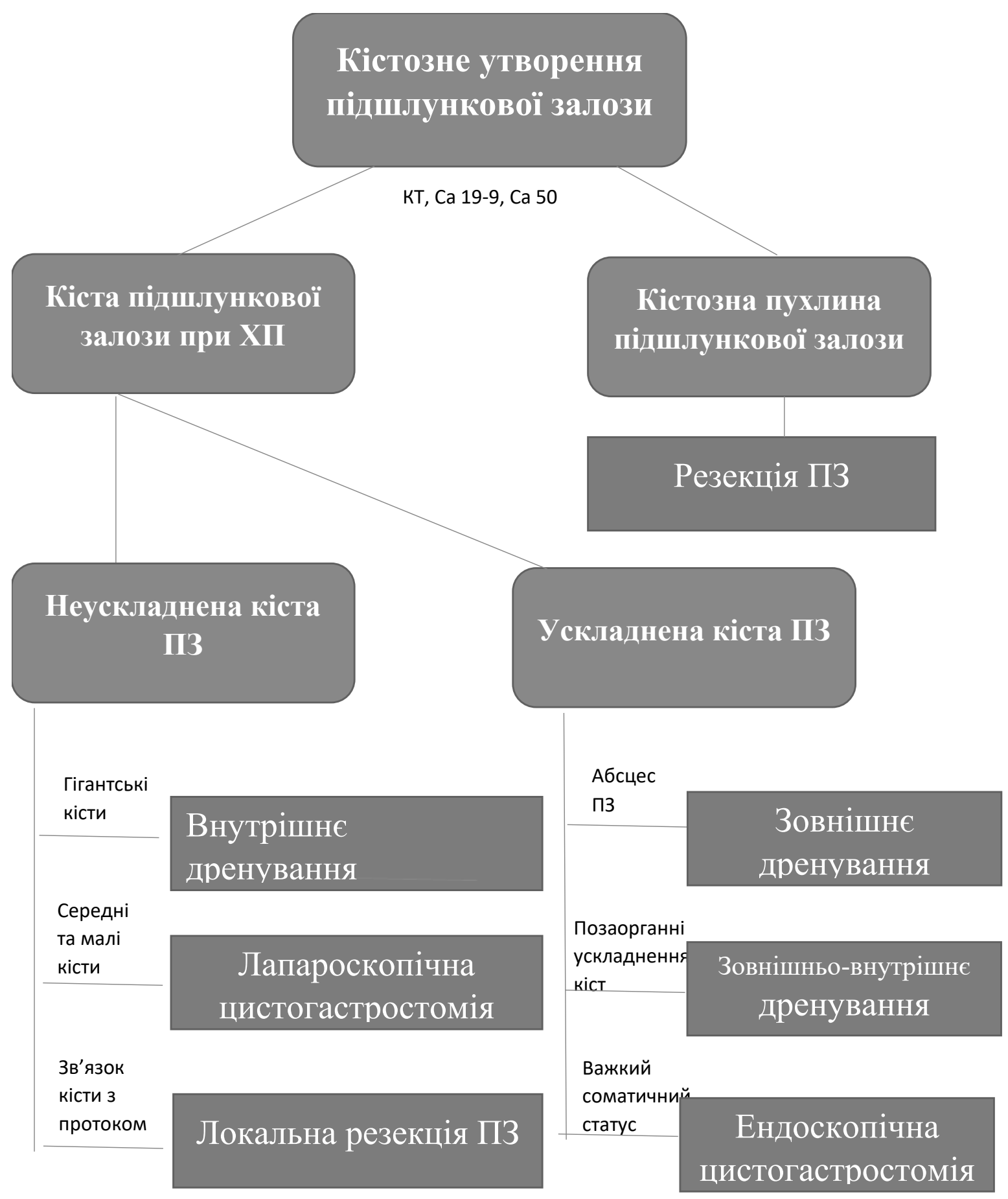

Рис. 3. Алгоритм вибору оперативного лікування у хворих з кістозними утвореннями підшлункової залози

Наявність зв'язку з головною панкреатичною протокою без іiі розширення не завжди вдавалося оцінити за даними комп'ютерної томографії. Тому такий зв'язок вважався наявний в випадку високого рівня амілази в просвіті кісти, який був діагностований в 79 хворого. Таким хворим, у випадку відсутності ускладнень (61), виконано внутрішню декомпресію кісти: цистоєюноанастомоз (46), цистодуоденоанастомоз (8), лапароскопічну цистогас- тростомію (6), відкриту цистогастростомію (1). Цистоєюнеостомію за Roux виконали у 37 (80,4\%), цистоєностомію 3 заглушкою привідної петлі - у $9(19,6 \%)$ (був застосований розроблений метод заглушки привідної петлі (Патент на корисну модель № 39289 від 25.02.2009). В даній групі не було випадків виникнення післяопераційної панкреатичної нориці. Післяопераційна летальність склала $0 \%$. 


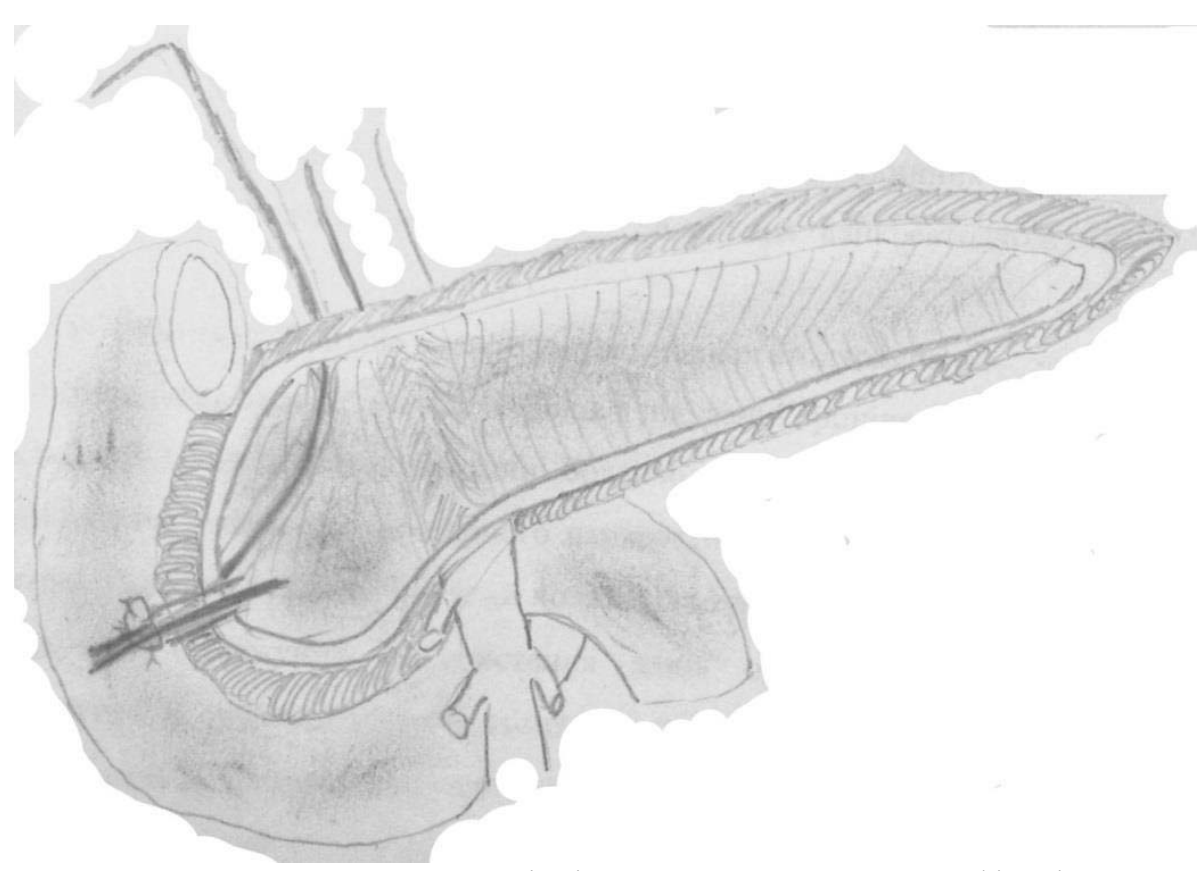

Рис. 2. Схема виконання локальної резекції підшлункової залози в модифікації Фрея-Ізбіцкого з транспанкреатичною папілосфінктеротомією

Серед використаних методів зовнішньої декомпресії (47) застосували у 29 зовнішне дренування кісти підшлункової залози і у 18 зовнішньовнутрішнє дренування. Показом до зовнішньої декомпресії був ускладнений перебіг кісти (абсцес (27) та кровотеча (2)). Кровотеча була зупинена за допомогою тампонади та аплікації полісорбу в порожнину кісти. В випадку інфікованого вмісту кісти, а також рівня амілази вище 512 Од виконували зовнішньо-внутрішню декомпресію.

Серед пацієнтів 3 зовнішньо-внутрішнім дренуванням нориці дебіт панкреатичного соку по дренажах з кісти різко зменшувався після відновлення пасажу по кишківнику (по закінченню газового періоду). У жодного хворого не виникло стійкої панкреатичної нориці.

Серед пацієнтів з зовнішнім дренування кісти, в післяопераційному періоді панкреатична нориця виникла у $10(34,4 \%)$ пацієнтів. У всіх цих хворих в просвіті кісти простежувався тиск II-III ступеня і складав $493 \pm 153$ мм Н2О. У 6 пацієнтів нориця самостійно закрилася протягом двох місяців (тип В) у 5 н них відзначалася панкреатична гіпертензія II ступеня. Натомість більше двох років після операції зовнішня нориця функціонувала у 1 хворого, який відмовлявся від оперативного лікування. Трьох хворих оперували повторно, в термін до 3-х місяців, що зумовлено з стійкою зовнішньою панкреатичною норицею (тип С). У всіх цих хворих був III ступінь панкреатичної гіпертензії (574 72 мм Н2О). Рецидив больового синдрому $(\mathrm{P}=7,1 \pm 0,22, \mathrm{BAШ}=7,7 \pm 0,31)$ протягом двох років констатовано у 4 хворих, яким виконали тільки зовнішне дренування кісти. Загалом серед 47 хворих рецидив больового синдрому констатовано у $14,9 \%(7)$.
У 5 хворих із вкрай важким станом (більше 30 балів за системою АРАCHЕ II) виконано ендоскопічну цистогастростомію.

Післяопераційна летальність склала 0,8\% (1 пацієнт) причиною смерті стала супутня патологія. Післяопераційні ускладнення виникли у 16,8\% (21 хворий), причому в 15 з зовнішнім дренуванням кісти. Рецидив больового синдрому був у $6(4,8 \%)$ хворих, що було причиною їх повторної госпіталізації та виконання локальної резекції підшлункової залози протягом 6 років. Рецидив больового синдрому виник у 2 пацієнтів з виконаною внуцтрішньою декомпресією та у 4 з зовнішньою.

Висновки. 1. У хворих на кісти підшлункової залози для вибору методу декомпресії необхідно враховувати крім тиску у просвіті кісти, також концентрацію панкреатичних ферментів (амілази) у вмісті кісти, розмір кісти, ііі співвідношення до інших органів та зв'язок з головною панкреатичною протокою.

2. У випадку наявності розширеної головної панкреатичної протоки та чіткого зв'язку з просвітом кісти таким хворим показані резекційні методи оперативного лікування.

3. Зовнішня декомпресія при рівні гіпертензії 23 супроводжується у $34,4 \%$ формуванням зовнішньої панкреатичної нориці, яка у 13,8\% не закривається самостійно і потребує виконання повторної операції, що загалом обумовлює неефективність цих методів для корекції панкреатичної гіпертензіі.

4. Внутрішня декомпресія не супроводжується збільшенням кількості післяопераційних ускладнень і летальності і дозволяє уникнути формування у післяопераційному періоді зовнішньої панкреатичної нориці. 
Інформація про конфлікт інтересів. Автори заявляють про відсутність конфлікту інтересів при виконанні наукового дослідження та підготовці даної статті.

Інформація про фінансування. Автори гарантують, що вони не отримували жодних винагород в будь-якій формі, здатних вплинути на результати роботи.

Особистий внесок кожного автора у виконання роботи:

Каніковський О.С. - розробка концепції і дизайну дослідження, аналіз отриманих даних, редагування;

Павлик І.В. - збір матеріалу, статистична обробка даних, підготовка тексту;

Олійник І.В. - збір матеріалу, аналіз отриманих даних, підготовка тексту;

Маховський О.Л. - збір матеріалу, аналіз отриманих даних, підготовка тексту.

\section{Список використаної літератури}

1. Pan G, Wan MH, Xie KL, Li W, Hu WM, Liu XB, et al. Classification and management of pancreatic pseudocysts. Medicine (Baltimore). 2015 Jun;94(24):e960. DOI: 10.1097/MD.0000000000000960

2. Anderson MA, Akshintala V, Albers KM, et al. Mechanism, assessment and management of pain in chronic pancreatitis: Recommendations of a multidisciplinary study group. Pancreatology. 2016;16(1):83-94. DOI: 10.1016/j.pan.2015.10.015

3. Teo K, Johnson MH, Drewes AM, Windsor JA. A comprehensive pain assessment tool (COMPAT) for chronic pancreatitis: Development, face validation and pilot evaluation. Pancreatology. 2017;17:706-19. DOI: 10.1016/j.pan.2017.07.004

4. Pavlyk I, Kanikovskiy O, Oliinyk I. The severity of pancreatic fibrosis- independent factor for choosing of type of surgical treatment in patients with chronic pancreatitis. Pancreatology. 2018;18(4)Supplement:188. DOI: 10.1016/j.pan.2018.05.452

5. Datta J, Vollmer CM. Advances in surgical management of pancreatic diseases. Journal of Gastroenterolology of Clinics of North America. 2016;45(1):129-44. DOI: 10.1016/j.gtc.2015.10.002

6. Ito $\mathrm{T}$, Ishiguro $\mathrm{H}$, Ohara $\mathrm{H}$, et al. Evidence-based clinical practice guidelines for chronic pancreatitis (2015). Journal of Gastroenterology. 2016;51(2):85-92. DOI: 10.1007/s00535-015-1149-x

Стаття надійшла до редакції: 4.08.2017 p. 